\title{
Subanesthetic Doses of Ketamine Stimulate Psychosis in Schizophrenia
}

Adrienne C. Lahti, M.D., Bettylou Koffel, M.D., David LaPorte, Ph.D., and Carol A. Tamminga, M.D.

We administered ketamine to schizophrenic individuals in a double-blind, placebo-controlled design using a range of subanesthetic doses $(0.1,0.3$, and $0.5 \mathrm{mg} / \mathrm{kg})$ to evaluate the nature, dose characteristics, time course, and neuroleptic modulation of $N$-methyl-D-aspartate (NMDA) antagonist action on mental status in schizophrenia. Ketamine induced a dose-related, short $(<30$ minutes) worsening in mental status in the haloperidol-treated condition, reflected by a significant increase in BPRS total score for the $0.3 \mathrm{mg} / \mathrm{kg}(\mathrm{p}=$ $.005)$ and $0.5 \mathrm{mg} / \mathrm{kg}(\mathrm{p}=.01)$ challenges. Positive symptoms (hallucinations, delusions, thought disorder), not negative symptoms accounted for these changes.
These ketamine-induced psychotic symptoms were strikingly reminiscent of the subject's symptoms during active episodes of their illness. Results from six patients who were retested in the same design after being neuroleptic-free for 4 weeks failed to indicate that haloperidol blocks ketamine-induced psychosis. Several subjects evidenced delayed or prolonged (8-24 hours) psychotomimetic effects such as worsening of psychosis with visual hallucinations. These data suggest that antagonism of NMDA-sensitive glutamatergic transmission in brain exacerbates symptoms of schizophrenia. [Neuropsychopharmacology 13:9-19, 1995]
KEY WORDS: Ketamine; Schizophrenia; Glutamate; Psychosis; Excitatory amino acids

Phencyclidine (PCP) was first introduced as an anesthetic drug in 1957 (Collins et al. 1960). Later, when it was noted to be psychotomimetic, it was withdrawn from medical use (Burns and Lerner 1976; Gupta et al. 1975). In its subsequent illicit use, the mental status effects of PCP in normal humans have been further clarified. At low doses PCP produces symptoms of inebriation and mild stimulation while at higher doses it causes perceptual alterations, depersonalization, and

From the Department of Psychiatry (ACL, DL, CAT), Maryland Psychiatric Research Center, University of Maryland School of Medicine, Baltimore, MD; the Department of Psychology (DL), University of Maryland-Baltimore County, Baltimore, MD; and the Department of Anesthesiology (BK), University of Maryland School of Medicine, Baltimore, MD.

Address correspondence to: Adrienne C. Lahti, M.D., Maryland Psychiatric Research Center, P.O. Box 21247, Baltimore, MD 21228.

Received June 8, 1994; revised November 23, 1994; accepted December 12, 1994. disturbances in cognition (Aniline and Pitts 1982; Luby et al. 1959; Pearlson 1981). On some occasions acute PCP psychosis in normal persons is indistinguishable from an acute episode of schizophrenia (Erard et al. 1980; Yesavage and Freeman 1978). Moreover, when given to schizophrenic patients, PCP has been noted to intensify their primary symptoms (Luby et al. 1959).

Although PCP is not available for use in humans, its structural analogue ketamine continues to be used as an anesthetic (White et al. 1982). Ketamine causes vivid dreams, experiences of depersonalization, derealization, and changes in mood and affect when used as an anesthetic in normal adults (Coppel et al. 1973; Fine and Finestone 1973; Freuchen et al. 1976; Heija and Galloon 1975; Moretti et al. 1984). But, it remains available because of desirable anesthetic characteristics for use in obstetrical patients, dental procedures in children, and emergency fieldwork. Experimentally, ketamine has been tested in normal humans in subanesthetic infusions; here it induces illusions, perceptual alterations, thought disorder, and 
emotional blunting (Krystal et al. 1994). The effects of ketamine in schizophrenia have not been previously described.

Ketamine, like $\mathrm{PCP}$, acts at the $\mathrm{PCP}$ receptor in the $\mathrm{N}$-methyl-D-aspartate (NMDA)-gated ionophore to block NMDA-sensitive glutamatergic transmission (Thomson et al. 1985). At this receptor a voltagesensitive, $\mathrm{Ca}^{2+}$ permeable channel is positively regulated by NMDA, glycine, and polyamines and blocked by PCP, $\mathrm{Mg}^{2+}$, and $\mathrm{Zn}^{2+}$ (Javitt and Zukin 1991a; Monyer et al. 1994; Watkins and Collingridge 1989). Ketamine acts at the PCP receptor with approximately one-tenth the potency of PCP. As such, ketamine opposes the action of NMDA by blocking ion flow through the channel and by attenuating the electrophysiological and intracellular consequences of glutamate stimulation at the NMDA receptor (Anis et al. 1983; Watkins and Collingridge 1989). When used at higher doses, ketamine has additional PCP-like neurochemical actions in brain, including those on the cholinergic, monoaminergic, and GABAergic systems (Castellani and Adams 1981; Malare et al. 1982; Nabeshima et al. 1981; Raja and Guyenet 1980; Tonge and Leonard 1969). Delayed neurophysiological and neurochemical actions also occur after PCP, and presumably after ketamine, including intracellular vacuolization (Olney et al. 1989), elevation of heat shock protein (Sharp et al. 1992), and a delayed hypometabolism (Gao et al. 1993). Although still poorly understood, some parts of the delayed changes may correlate with the delayed psychotomimetic actions of PCP in humans, described as flashbacks (Aniline and Pitts 1982; Rainey and Crowder 1975).

Glutamatergic transmission has been studied for its involvement in the pathophysiology of schizophrenia, primarily based on the psychotomimetic profile of PCP in humans and its antagonism of the NMDA receptor (Anis et al. 1983). In addition, a decrease in glutamate concentration in the cerebrospinal fluid of schizophrenic patients was reported by Kim et al. (1991), but the finding has not been consistently replicated (Gattaz et al. 1985; Korpi et al. 1987; Macciardi et al. 1990). Moreover, postmortem schizophrenia studies have suggested alterations in glutamatergic transmission; changes in the density of various of the glutamate receptors in cortical areas (Deakin et al. 1989; Kerwin et al. 1990; Kurumaji et al. 1992; Nishikawa et al. 1993; Suga et al. 1990; Toru et al. 1988; Ulas and Cotman 1993) and in the putamen (Kornhuber et al. 1989), as well as a decrease in NMDA-mediated glutamate release from human postmortem synaptosomes (Sherman et al. 1991) have been reported. Overall, these studies raise the possibility of a reduction in glutamatergic transmission in schizophrenia and prompt the search for ways pharmacologically to manipulate the glutamate system to test these ideas further (Potkin et al. 1992; Tamminga et al. 1992).
The goals of the present study were to describe the action and time course of subanesthetic doses of ketamine on mental status in schizophrenic patients. In addition, we wanted to evaluate the effect of haloperidol on ketamine-induced symptoms in this already psychotic patient population.

\section{METHODS}

\section{Subjects}

Nine schizophrenic patient volunteers participated in the study while hospitalized on an inpatient research unit. They and their families were fully informed about the nature of the protocol and the potential side effects of ketamine (including psychosis exacerbation), and each gave informed consent. The protocol and consent form were approved for use by the University of Maryland Internal Review Board (IRB). The IRB initially approved the research and gave detailed and ongoing review of this project during its conduct, especially when the mental status consequences of ketamine in schizophrenia became apparent. For ethical reasons the number of patients who could be recruited to participate was restricted by the IRB to the minimum number to answer the questions posed.

Clinical demographics of the nine patients together with characteristics of their symptoms are detailed in Table 1. Five males and four females participated; their mean age was $30( \pm 9.3)$ and mean length of illness was 9.3 years $( \pm 6.2)$. They received a psychiatric diagnosis of schizophrenia using DSM-III-R criteria, as made by two experienced clinicians, based on all historical and direct assessment information available. Each participant was evaluated using the Structural Clinical Interview Diagnosis (SCID), the Schedule for the Deficit Syndrome (SDS) (Kirkpatrick et al. 1989), the MPRC Involuntary Movement Scale (IMS) (Smith et al. 1980), the Neurological Evaluation Scale (NES) (Buchanan and Heinrichs 1989), the Cannon-Spoor Premorbid Adjustment Scale (PAS) (Cannon-Spoor et al. 1982), the Prognostic Scale (PRO) (Strauss and Carpenter 1974). Moreover, each participant had a detailed clinical psychiatric history and family history for mental illness, with extensive contact with past treatment facilities and/or family members. Each of these subjects was medically healthy by history and free of current significant disease by physical and laboratory examination. None of these patients had a recent history of drug or alcohol abuse.

\section{Experimental Overview}

All volunteers were actively psychotic, but stable, inpatients on a clinical research ward. Each was on a fixed dose of haloperidol (HAL) $(0.3 \mathrm{mg} / \mathrm{kg} /$ day) for 4 weeks 
Table 1. Demographics

\begin{tabular}{|c|c|c|c|c|c|c|c|c|c|c|c|c|}
\hline $\begin{array}{l}\text { Patient } \\
\text { No. }\end{array}$ & Sex & Race & Age & $\begin{array}{l}\text { Length } \\
\text { of Illness } \\
\text { (years) }\end{array}$ & Diagnosis & $\begin{array}{c}\text { Deficit }^{a} \\
\text { Symptoms }\end{array}$ & $\begin{array}{l}\text { Thought } \\
\text { Disorder }\end{array}$ & $\begin{array}{c}\text { Hallucinations }{ }^{c /} \\
\text { Delusions }\end{array}$ & IMS $^{d}$ & NES $^{e}$ & PAS $f$ & PROs \\
\hline 1 & $\mathrm{~F}$ & A & 28 & 9 & Schizo./paranoid & + & 1 & 6.5 & 3 & 18 & 0.20 & 2 \\
\hline 2 & $\mathrm{~F}$ & B & 28 & 4 & Schizo./paranoid & - & 1 & 2.0 & 7 & 23 & 0.01 & 1 \\
\hline 3 & M & W & 28 & 8 & Schizo./paranoid & - & 1 & 5.0 & 0 & NA & 0.27 & 5 \\
\hline 4 & $\mathrm{M}$ & W & 23 & 7 & Schizo./disorg. & - & 4.5 & 5.8 & 7 & 22 & 0.26 & 1 \\
\hline 5 & $\mathbf{M}$ & W & 22 & 3 & Schizo./paranoid & - & 1 & 4.8 & 0 & 12 & 0.48 & 6 \\
\hline 6 & $\mathrm{M}$ & $\mathrm{B}$ & 25 & 8 & Schizo./paranoid & - & 1 & 4.0 & 4 & 21 & 0.03 & 5 \\
\hline 7 & $\mathbf{M}$ & B & 29 & 8 & Schizo./paranoid & - & 1.5 & 5.5 & 8 & 12 & 0.15 & 5 \\
\hline 8 & $\mathrm{~F}$ & $\mathrm{~A}$ & 53 & 24 & Schizo./undiff. & - & 3.7 & 6.0 & 13 & 27 & 0.22 & 0 \\
\hline 9 & $\mathrm{~F}$ & W & 34 & 13 & Schizo./undiff. & - & 4.0 & 7.3 & 3 & 56 & 0.56 & 0 \\
\hline
\end{tabular}

Abbreviations: schizo. = schizophrenia, disorg. = disorganized, undiff. = undifferentiated.

${ }^{a}$ Primary negative symptoms.

${ }^{b}$ BPRS: Item \#4.

$c$ BPRS: Item \#12 and \#15.

${ }^{d}$ MPRC Involuntary Movement Scale: Tardive Dyskinesia Global Rating.

${ }^{e}$ Neurological Evaluation Scale: Total Score.

$f$ Premorbid Adjustment Scale: Age Scales Total Score (lower score is better).

8 Prognostic Scale: General Items Total Score (higher score is better).

prior to the first ketamine dosing. Ketamine action was evaluated as will be described; our intention was to study ketamine in the patients both on and off haloperidol. After the initial on-HAL procedure, each ketamine subject was invited to participate in a neuroleptic withdrawal period which involved a blinded, placebo-controlled haloperidol withdrawal and a drugfree period of 4 to 8 weeks, conducted independent of this protocol. An identical ketamine administration was repeated after haloperidol withdrawal. Six of the nine patients completed the drug-free period and received a second ketamine administration without haloperidol (off-HAL). Three patients did not proceed with drugfree testing. One was discharged from the hospital for reasons independent of this protocol and the other two refused the repeat procedure, because they disliked their previous experience with ketamine. One of those two patients had a mild response after ketamine and the other one had a large response for all three dosages. Ketamine effects in both situations were identically assessed and blindly rated using the scales described. An extensive program of milieu, rehabilitation, and psychosocial treatment is conducted for all subjects during their hospitalization, effective when patients are with or without neuroleptic treatment.

\section{Ketamine Administration Procedure}

The ketamine procedure consisted of four intravenous injections: three doses of ketamine $(0.1,0.3$, and 0.5 $\mathrm{mg} / \mathrm{kg}$ ) and one of placebo; medication was intravenously administered over 60 seconds. One dose was given on each of four different days spaced over 2 weeks. The order of drug dose and placebo was selected by the nonblind staff for safety reasons; one physician (CT) and one research nurse were not blind to drug but were uninvolved in clinical assessments. Eleven different drug dose orders were used in the fifteen studies ( $n=9$, on-HAL; $n=6$, off-HAL). The highest dose was routinely not given first. On the day of the experiment and 1 hour prior to injection, an indwelling catheter was placed in the forearm, while the patient was comfortably positioned in a quiet room with familiar staff members. An EKG monitor was used to monitor cardiac status continuously for 30 minutes after ketamine; pulse, blood pressure and blood oxygen saturation were also closely monitored. Ratings of mental status were made at baseline and at 20,90 , and 180 minutes after the drug administration. These ratings were the BPRS and the SANS global items; they were scored from a clinical interview which summed all events which occurred since the previous rating. Six of the nine participants were drug-free for at least 4 weeks after their initial ketamine procedure; then they were retested with a second identical ketamine procedure. Overall, three subjects failed to receive the highest ketamine dose, two for safety reasons (as judged by the nonblind observer with the blind preserved) and one because of an unrelated infection. The first two subjects received placebo blindly as a dose substitution.

\section{Mental Status Evaluation}

Mental status was evaluated using the Brief Psychiatric Rating Scale (BPRS) (Overall and Gorham 1962) and the Assessment of Negative Symptoms Scale (SANS) (Andreasen 1982). For this experiment patients were evaluated using these two instruments on the day of the infusion just prior to ketamine/placebo administration and again at 20,90, and 180 minutes after drug injection. The BPRS total score was evaluated as well as its subscale scores: psychosis (items: \#4, \#12, and \#15), 
withdrawal (items: \#3, \#13, and \#16), activation (items: $\# 6$, \#7, and \#17), anxiety (items: \#1, \#2, \#5, and \#9), and hostility (items: \#10, \#11, and \#14) (Guy 1976; Hedlund and Vieweg 1980). The global SANS items were used for negative symptoms. Mental status ratings were conducted blindly by a single research clinician; sessions were audiotaped to allow for the subsequent review of each subject's responses for the case reports. Moreover, detailed timely clinical notes were taken by the blind clinician, to describe the responses. A follow-up clinical interview, again conducted blind to the drug or dose was done at 8 and 24 hours postinjection by the same clinician to review the experience of the drug and dose.

\section{Data Analysis}

A multivariate repeated measures analysis of variance with dose as the repeated factor was conducted at each time point with planned orthogonal contrasts comparing the three dose levels to placebo. The same strategy was used to analyze the data on and off haloperidol. Paired $t$-tests were used to compare the average baseline scores on-HAL to the average baseline scores off-HAL.

\section{RESULTS}

\section{Ketamine in Haloperidol-Treated Subjects}

Ketamine increased total BPRS score 20 minutes after injection in a dose-sensitive fashion (Figure 1 and Table 2). The increase at 20 minutes was significant for the 0.3- $(p=.005)$ and $0.5-(p=.01) \mathrm{mg} / \mathrm{kg}$ dose. The BPRS score returned to baseline by 90 and 180 minutes. The BPRS psychosis subscale score largely accounted for the total BPRS change at 20 minutes; the increase in positive psychotic symptoms at 20 minutes was significant at the $0.1-\mathrm{mg} / \mathrm{kg}(p=.05)$ and $0.5-\mathrm{mg} / \mathrm{kg}\left(p^{-}=\right.$ $.02)$ dose. Seven of the nine patients showed at least a $50 \%$ increase in psychosis during the ketamine injections; one showed a change less than $25 \%$ and one patient failed to change. The latter patient was the oldest and had a longer length of illness than any other volunteer (patient 8 , Table 1 ). At the $0.1-\mathrm{mg} / \mathrm{kg}$ ketamine doses, these subjects reported the experience of perceptual distortions, illusions, and depersonalization. At the $0.3-$ and $0.5-\mathrm{mg} / \mathrm{kg}$ doses, they evidenced suspiciousness, delusions, typical hallucinations (visual and auditory), and thought disorder (looseness of associations, incoherence, flight of ideas).

Ketamine failed to alter negative mental symptoms in these patients overall (Table 2). Typically, during the first 3 to 5 minutes after drug administration, patients would appear withdrawn, without spontaneous communication, but were always responsive; they often closed their eyes and appeared to attend to internal

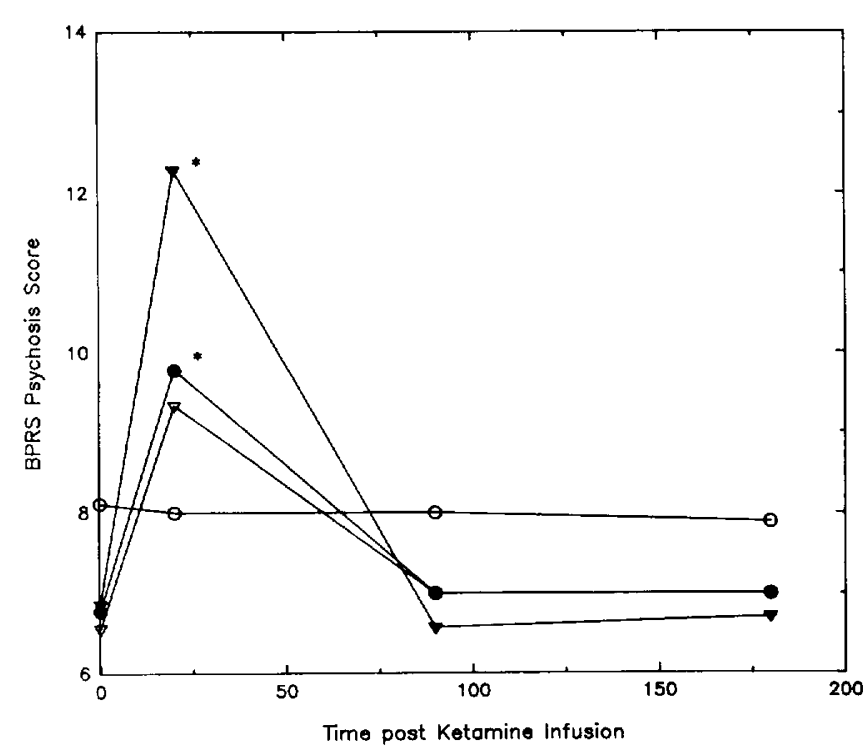

Figure 1. Ketamine challenges in haloperidol-treated subjects (time post ketamine infusion in minutes). Time course of mental status changes after acute injection of ketamine 0.1 $\mathrm{mg} / \mathrm{kg}$ (filled circles), $0.3 \mathrm{mg} / \mathrm{kg}$ (open triangles), $0.5 \mathrm{mg} / \mathrm{kg}$ (filled triangles), and placebo (open circles) in haloperidol-treated subjects $(n=9)$. ${ }^{*} p<.05$ denotes significant increase from placebo condition.

stimuli. Later, in interview, the subjects reported active mental events during this initial postdrug time. Only two of the nine patients had prominent enduring negative symptoms at diagnosis and met criteria for the diagnosis of deficit syndrome (SDS). Of these, one experienced a worsening of negative symptoms by $50 \%$ with ketamine, whereas the other subject's negative symptoms improved by $60 \%$; positive symptoms increased in both subjects.

There was no significant increase in anxiety (BPRS subscale, Table 2) with ketamine at any time or any dose except with $0.3 \mathrm{mg} / \mathrm{kg}$ at 180 minutes. Within each dose level, there was a tendency for anxiety scores to decrease over the 180-minute experiment. The lack of symptom change on these as well as the other subscales (activation and hostility) of the BPRS suggests a selective ketamine action on positive psychotic symptoms.

During the follow-up clinical interviews at 8 and 24 hours, four out of nine patients spontaneously reported the reoccurrence of their psychotic responses at a delayed time after ketamine. Two patients experienced a recurrence of ketamine-induced delusions approximately 6 to 8 hours after ketamine; the magnitude however, was less than that of their original mental status change. This delayed effect lasted for several hours and was not severe; no treatment was required. Both patients were asymptomatic 24 hours later and remained so. One patient reported active dreaming the night after his ketamine infusions, and a fourth patient reported flashbacks of the exact visual hallucinations 
Table 2. Ketamine Effect in Haloperidol-Treated Subjects

\begin{tabular}{|c|c|c|c|c|}
\hline \multirow[b]{2}{*}{ Minutes } & \multicolumn{4}{|c|}{ Haloperidol-Treated Subjects } \\
\hline & $\begin{array}{c}\text { PBO } \\
(n=9)\end{array}$ & $\begin{array}{c}0.1 \mathrm{mg} / \mathrm{kg} \\
(n=9)\end{array}$ & $\begin{array}{c}0.3 \mathrm{mg} / \mathrm{kg} \\
(n=9)\end{array}$ & $\begin{array}{c}0.5 \mathrm{mg} / \mathrm{kg} \\
(n=7)\end{array}$ \\
\hline \multicolumn{5}{|c|}{ BPRS Total Score } \\
\hline 0 & $34.6(7.0)$ & $33.2(4.2)$ & $35.2(5.4)$ & $36.9(11.0)$ \\
\hline 20 & $33.4(6.0)$ & $38.3(7.1)$ & $39.3(5.0)^{a}$ & $45.3(7.7)^{a}$ \\
\hline 90 & $32.6(5.2)$ & $30.9(3.2)$ & $33.4(4.3)$ & $32.3(5.6)$ \\
\hline 180 & $31.1(4.1)$ & $29.6(4.1)$ & $33.7(3.8)$ & $32.3(8.0)$ \\
\hline \multicolumn{5}{|c|}{ BPRS Psychosis Subscale } \\
\hline 0 & $8.1(3.1)$ & $6.8(2.9)$ & $6.6(3.0)$ & $6.9(2.9)$ \\
\hline 20 & $8.0(3.1)$ & $9.8(3.3)^{b}$ & $9.3(2.8)$ & $12.3(2.5)^{b}$ \\
\hline 90 & $8.0(3.0)$ & $7.0(2.5)$ & $7.0(2.8)$ & $6.6(2.9)$ \\
\hline 180 & $7.9(3.0)$ & $7.0(2.6)^{b}$ & $7.0(2.8)$ & $6.7(3.0)$ \\
\hline \multicolumn{5}{|c|}{ BPRS Withdrawal Subscale } \\
\hline 0 & $7.1(2.6)$ & $8.2(3.0)$ & $8.0(2.7)$ & $7.3(2.8)$ \\
\hline 20 & $7.6(3.3)$ & $8.9(3.9)$ & $8.8(3.9)$ & $8.6(4.1)$ \\
\hline 90 & $7.0(2.6)$ & $6.9(3.4)$ & $6.6(3.1)$ & $5.9(2.5)$ \\
\hline 180 & $6.6(2.7)$ & $6.6(3.5)$ & $6.6(3.4)$ & $5.3(2.6)$ \\
\hline \multicolumn{5}{|c|}{ BPRS Anxiety Subscale } \\
\hline 0 & $7.2(3.4)$ & $6.2(2.1)$ & $8.0(4.4)$ & $8.9(4.7)$ \\
\hline 20 & $6.3(2.7)$ & $7.1(2.9)$ & $7.4(3.7)$ & $9.3(3.8)$ \\
\hline 90 & $5.4(2.4)$ & $6.0(2.2)$ & $7.3(3.7)$ & $7.1(2.5)$ \\
\hline 180 & $5.6(2.5)$ & $5.1(1.7)$ & $7.3(3.5)^{b}$ & $6.9(2.9)$ \\
\hline
\end{tabular}

${ }_{b}^{a} p<.01$.

${ }^{b} p<.05$.

experienced during the challenge, recurring occasionally throughout the next several days. Later, this patient refused the second (off-HAL) set of ketamine infusions because she found these flashbacks unpleasant. These data are descriptive and were gathered by clinical report, not systematically rated, because no delayed effects had been anticipated.

There was a remarkable similarity between the themes and content of the psychotic symptoms induced by ketamine and the symptoms known to be associated with the patients' schizophrenic illness. This was true for delusions, thought disorder, and hallucinations. Two patients known to have characteristic and extensive paranoid delusions, reactivated part of these specific delusions with ketamine. Some patients without thought disorder while taking haloperidol, became disorganized after ketamine in ways characteristic of their untreated illness. Visual hallucinations were frequent in all the patients. While some appeared to be typical schizophrenic hallucinations, others had a dreamlike quality. Only one patient presented a typical auditory hallucination in the form of voices speaking to him. Table 3 details symptoms each patient experienced during their usual illness exacerbations and the symptoms which occurred with ketamine, including the delayed effects after drug, where present.

\section{Ketamine in Neuroleptic-Free Subjects}

Six of the nine patients underwent an additional blinded series of ketamine infusions when they were neuroleptic-free (off-HAL). In these comparisons, the total BPRS score showed a trend toward worsening at 20 minutes after ketamine for the 0.5-mg ketamine dose $(p=0.07)$ (Table 4). There were no other significant mental status changes in symptoms of anxiety or withdrawal 20 minutes after ketamine in the neurolepticfree subjects. The increase in the BPRS withdrawal score was significant $(p<.05)$ at 180 minutes for the $0.5-\mathrm{mg} / \mathrm{kg}$ dose $(n=5)$. When looking at the same subjects $(n=$ 6) in the on-HAL condition, there was also only a trend toward worsening at 20 minutes for the $0.5-\mathrm{mg}$ dose $(p<.1)$ on the BPRS total score, and the increase in the BPRS psychosis score at 20 minutes was not significant for any of the ketamine doses (Figure 2).

To evaluate whether the magnitude of the ketamine effect was different in the on- and off-HAL condition, we compared the increase in BPRS total score and psychosis score at 20 minutes between conditions for those six patients (Figure 2). The increase in BPRS total and psychosis score was not statistically different between conditions. Likewise, we compared the baseline BPRS total and psychosis score between the on- and off-HAL 
Table 3. Ketamine in Haloperidol-Treated Schizophrenic Patients

\begin{tabular}{|c|c|c|c|}
\hline Subject/Diagnosis & $\begin{array}{l}\text { Acute Disease } \\
\text { Symptoms }\end{array}$ & $\begin{array}{c}\text { Acute Drug Effects } \\
(20 \text { min. })\end{array}$ & $\begin{array}{c}\text { Delayed Drug Effects } \\
(4-24 \text { hr) }\end{array}$ \\
\hline $\begin{array}{l}\text { 1, Female/schizophrenia, } \\
\text { paranoid }\end{array}$ & $\begin{array}{l}\text { Religious delusions, } \\
\text { auditory and visual } \\
\text { hallucinations, } \\
\text { withdrawal, anhedonia, } \\
\text { blunted affect }\end{array}$ & $\begin{array}{l}\text { Atypical visual } \\
\text { hallucinations, reduced } \\
\text { withdrawal and } \\
\text { blunted affect }\end{array}$ & None reported \\
\hline $\begin{array}{l}\text { 2, Female/schizophrenia, } \\
\text { paranoid }\end{array}$ & $\begin{array}{l}\text { Grandiose delusions, } \\
\text { withdrawal, } \\
\text { anhedonia, } \\
\text { blunted affect }\end{array}$ & $\begin{array}{l}\text { Suspiciousness, visual } \\
\text { hallucinations, increased } \\
\text { withdrawal and } \\
\text { blunted affect }\end{array}$ & $\begin{array}{l}\text { Reported experience } \\
\text { of visual } \\
\text { hallucinations } \\
\text { (several days) }\end{array}$ \\
\hline $\begin{array}{l}\text { 3, Male/schizophrenia, } \\
\text { paranoid }\end{array}$ & $\begin{array}{l}\text { Extensive delusions } \\
\text { of control, auditory } \\
\text { hallucinations }\end{array}$ & $\begin{array}{l}\text { Perceptual distortions- } \\
\text { illusions, increased } \\
\text { suspiciousness, } \\
\text { delusions of control, } \\
\text { auditory hallucinations, } \\
\text { atypical visual } \\
\text { hallucinations }\end{array}$ & $\begin{array}{l}\text { Delusions of control } \\
\text { (lasted } 12 \text { hrs) }\end{array}$ \\
\hline $\begin{array}{l}\text { 4, Male/schizophrenia, } \\
\text { disorganized }\end{array}$ & $\begin{array}{l}\text { Paranoid delusions, } \\
\text { thought disorder } \\
\text { (loose associations), } \\
\text { visual hallucinations }\end{array}$ & $\begin{array}{l}\text { Increased thought disorder } \\
\text { (0.1 mg), decreased } \\
\text { thought disorder } \\
(0.5 \mathrm{mg}) \text {, paranoid } \\
\text { ideation, visual } \\
\text { hallucinations }\end{array}$ & $\begin{array}{l}\text { Nightmares while } \\
\text { sleeping ( } 2 \text { nights) }\end{array}$ \\
\hline $\begin{array}{l}\text { 5, Male/schizophrenia, } \\
\text { paranoid }\end{array}$ & $\begin{array}{l}\text { Persecurtory } \\
\text { delusions, auditory } \\
\text { and visual } \\
\text { hallucinations }\end{array}$ & $\begin{array}{l}\text { Perceptual distortions- } \\
\text { illusions, atypical visual } \\
\text { hallucinations }\end{array}$ & None reported \\
\hline $\begin{array}{l}\text { 6, Male/schizophrenia, } \\
\text { paranoid }\end{array}$ & $\begin{array}{l}\text { Grandiose delusions, } \\
\text { visual hallucinations }\end{array}$ & Grandiose delusions & None reported \\
\hline $\begin{array}{l}\text { 7, Male/schizophrenia, } \\
\text { paranoid }\end{array}$ & $\begin{array}{l}\text { Grandiose delusions, } \\
\text { thought disorder } \\
\text { (word salad) }\end{array}$ & $\begin{array}{l}\text { Disorganized thought } \\
\text { (word salad), grandiose } \\
\text { delusions }\end{array}$ & $\begin{array}{l}\text { Recurrence of delu- } \\
\text { sions sustained } \\
\text { over } 12 \text { hours }\end{array}$ \\
\hline $\begin{array}{l}\text { 8, Female/schizophrenia, } \\
\text { undifferentiated }\end{array}$ & $\begin{array}{l}\text { Visual hallucinations, } \\
\text { thought disorder } \\
\text { (loose associations) }\end{array}$ & No change & None reported \\
\hline $\begin{array}{l}\text { 9, Female/schizophrenia, } \\
\text { undifferentiated }\end{array}$ & $\begin{array}{l}\text { Auditory hallucinations, } \\
\text { thought disorder } \\
\text { (loose associations, } \\
\text { thought blocking) }\end{array}$ & Auditory hallucinations & None reported \\
\hline
\end{tabular}

${ }^{a}$ Symptoms experienced during acute exacerbation of illness.

condition. Although all subjects presented a worsening of symptoms during the neuroleptic-free period, the overall effect was not significant.

\section{Case Vignettes}

Case \#1. $\mathrm{AB}$ is a 29-year-old male paranoid schizophrenic. He is a robust neuroleptic responder, who on haloperidol presents few psychotic symptoms and little or no thought disorder. On ketamine, he experienced both an increase in disorganized thought (neologisms, flight of ideas, loose association), suspiciousness, and paranoid delusions. At $0.1 \mathrm{mg}$ he became mildly suspicious; at $0.3 \mathrm{mg}$ he presented moderate thought disorganization and paranoid delusion; and at $0.5 \mathrm{mg}$ he was floridly delusional, commenting on how he rescued the president of the United States from an assassination attempt. After the $0.5-\mathrm{mg} / \mathrm{kg}$ dose, his symptoms resolved quickly, but he remained slightly symptomatic at the 3-hour assessment period. Eight hours after ketamine he became actively psychotic again, with delusions of the same theme. The following morning with no other drug treatment, he was asymptomatic. During a later drug-free period unrelated to this study his clinical symptoms were that of paranoid schizophrenia; his delusional system involved his working for the CIA and protecting the president of the United States; moreover, he evidenced a significant increase in thought disorder. There were similarities between his disease symptoms and those induced by ketamine. 
Table 4. Ketamine Effect in Neuroleptic-Free Subjects

\begin{tabular}{|c|c|c|c|c|}
\hline \multirow[b]{2}{*}{ Minutes } & \multicolumn{4}{|c|}{ Neuroleptic-Free Subjects } \\
\hline & $\begin{array}{c}\text { PBO } \\
(n=6)\end{array}$ & $\begin{array}{c}0.1 \mathrm{mg} / \mathrm{kg} \\
(n=6)\end{array}$ & $\begin{array}{c}0.3 \mathrm{mg} / \mathrm{kg} \\
(n=6)\end{array}$ & $\begin{array}{c}0.5 \mathrm{mg} / \mathrm{kg} \\
(n=5)\end{array}$ \\
\hline \multicolumn{5}{|c|}{ BPRS Total Score } \\
\hline 0 & $38.3(7.2)$ & $40.2(6.7)$ & $40.8(6.4)$ & $40.4(4.3)$ \\
\hline 20 & $37.3(7.5)$ & $38.5(5.6)$ & $44.7(7.4)$ & $46.6(5.9)^{a}$ \\
\hline 90 & $36.7(7.2)$ & $35.5(6.9)$ & $38.7(3.4)$ & $39.0(4.4)$ \\
\hline 180 & $36.0(6.2)$ & $35.4(6.9)$ & $38.3(3.8)$ & $38.2(4.3)$ \\
\hline \multicolumn{5}{|c|}{ BPRS Psychosis Subscale } \\
\hline 0 & $10.0(5.1)$ & $10.5(4.9)$ & $9.8(4.3)$ & $10.6(3.6)$ \\
\hline 20 & $10.0(5.1)$ & $11.3(5.0)$ & $11.8(3.8)$ & $12.4(3.5)$ \\
\hline 90 & $10.0(5.1)$ & $10.5(4.2)$ & $10.3(4.1)$ & $11.4(3.7)$ \\
\hline 180 & $9.8(4.8)$ & $10.4(4.7)$ & $9.8(4.1)$ & $38.2(4.3)$ \\
\hline \multicolumn{5}{|c|}{ BPRS Withdrawal Subscale } \\
\hline 0 & $10.0(6.3)$ & $10.7(6.4)$ & $11.5(5.5)$ & $10.8(5.5)$ \\
\hline 20 & $10.2(6.5)$ & $10.0(5.2)$ & $11.0(6.2)$ & $13.2(6.4)$ \\
\hline 90 & $9.7(6.1)$ & $9.5(5.4)$ & $9.3(3.8)$ & $10.6(5.6)$ \\
\hline 180 & $9.5(6.1)$ & $8.8(4.9)$ & $9.8(3.5)$ & $11.0(6.0)^{b}$ \\
\hline \multicolumn{5}{|c|}{ BPRS Anxiety Subscale } \\
\hline 0 & $5.5(2.0)$ & $5.8(3.0)$ & $6.0(1.4)$ & $5.6(3.1)$ \\
\hline 20 & $5.0(1.3)$ & $5.0(1.6)$ & $5.7(2.7)$ & $7.2(2.4)$ \\
\hline 90 & $4.7(1.2)$ & $4.8(1.3)$ & $5.8(3.0)$ & $4.8(1.8)$ \\
\hline 180 & $4.7(1.2)$ & $5.0(1.4)$ & $5.7(2.7)$ & $4.0(0.0)$ \\
\hline
\end{tabular}

${ }_{b}^{a} p<.1$.

$b p<.05$.

Case \#2. CD is a 28-year-old paranoid schizophrenic female who met criteria for the deficit syndrome. While treated with haloperidol, she had few positive symptoms but remained blunted and withdrawn. With a low dose of ketamine $(0.1 \mathrm{mg} / \mathrm{kg})$ she experienced body distortions. With the $0.3-\mathrm{mg} / \mathrm{kg}$ dose she reported changes in visual perceptions and suspiciousness. At $0.5 \mathrm{mg} / \mathrm{kg}$, she experienced full visual hallucinations of human faces and of a mall at Christmas with the "snowman and gifts." Simultaneously, she became less blunted and more communicative. Six hours after the first challenge she became more delusional (paranoid theme centered around mother) and reported more hallucinations (visual and auditory). When $C D$ was neuroleptic-free, she became highly suspicious and presented delusions with religious themes. She expe-
Figure 2. Comparison of BPRS psychosis score at baseline (open bars) and 20 minutes (hatched bars) after three doses of ketamine $(0.1,0.3,0.5$ $\mathrm{mg} / \mathrm{kg}$ ) and placebo (PBO) in subjects $(n=6)$ who received challenges both on (on-HAL) and off (off-HAL) haloperidol. With this small number of subjects, the increase in psychosis score after $\mathbf{2 0}$ minutes was not significant for either the onor off-HAL conditions. Neither the increase in BPRS psychosis score nor the BPRS psychosis score at baseline were significantly different between conditions.

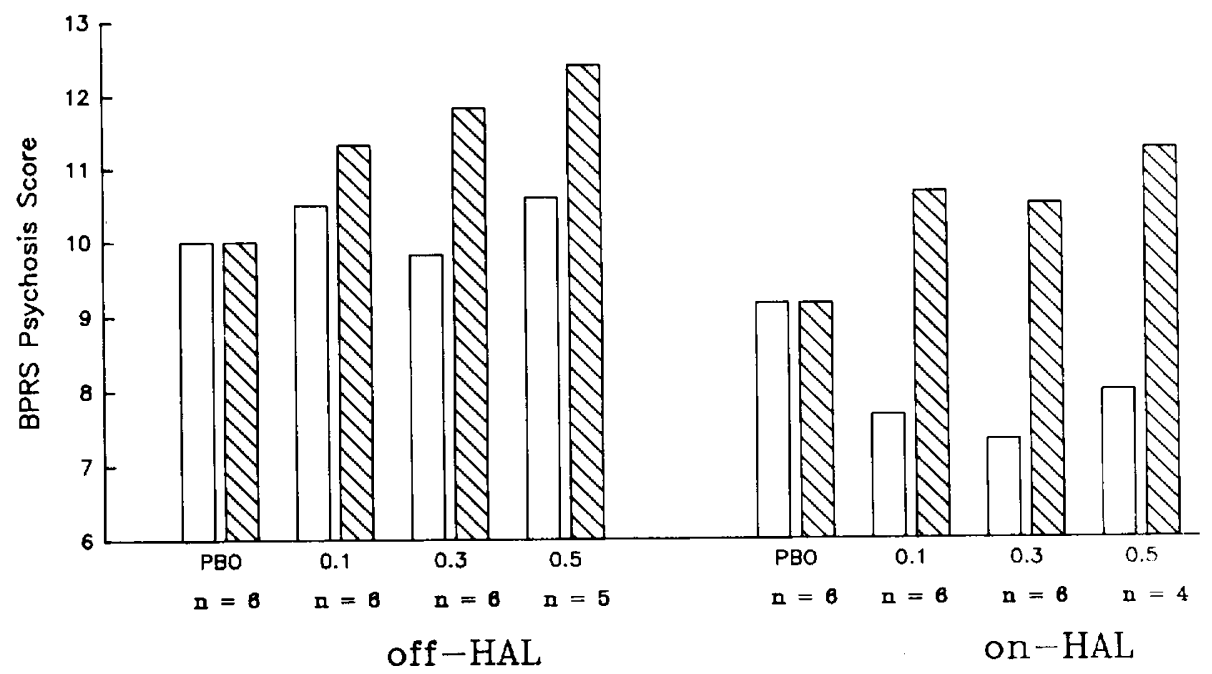


rienced auditory (voices commenting on her behavior) and visual hallucinations (of God and her mother). She remained blunted and withdrawn while drug-free.

\section{DISCUSSION}

The data presented here show a dose-dependent, shortlasting, but reproducible, increase in psychotic symptoms after subanesthetic doses of ketamine in schizophrenic individuals. Some of the ketamine-induced symptoms were remarkably similar to symptoms those patients had already experienced during active episodes of their illness. Delusion themes and thought disorder, familiar to the schizophrenic individual, were strikingly conserved in subjects during the ketamine challenges. The ability of PCP, a congener of ketamine, to trigger symptoms that strongly resemble schizophrenia was referred to by Luby over three decades ago; he said, "It was as though the acute phase of the illness had been reinstated" (Luby et al. 1959). Although many symptoms were similar to the patients' own acute symptoms, other ketamine-induced mental status changes were different. Some patients reported visual hallucinations which had a "dreamlike" quality, as though the patients themselves were actively participating in the phenomena. These atypical hallucinations have been reported by both patients and normal subjects receiving PCP (Krystal et al. 1994; Luby et al. 1959).

No overall change in negative symptoms was observed with ketamine. These findings are in contrast to descriptions of PCP-induced dissociation in normals that previously led observers to predict that negative symptoms would be associated with PCP or ketamine in schizophrenia (Bakker and Amini 1961; Javitt et al. 1991b). Descriptively, subjects in this study were behaviorally withdrawn in the furst few minutes after ketamine administration; nonetheless, they later reported very active mental processes during this time with illusions, hallucinations, and delusional activation. At the 20-minute postdrug evaluation, subjects reported no increase in withdrawal symptoms. Moreover, schizophrenic patients who began the study with prominent negative symptoms failed to consistently show worsening of those symptoms, even though their positive psychotic symptoms increased; however, this patient number $(n=2)$ was very low. Anxiety as rated here did not show a relationship to ketamine administration. Anxiety scores began relatively high at baseline and dissipated with procedure familiarity. We would suggest that the anxiety was anticipatory in nature and that its reduction was related to the successful completion of the procedure.

There have been conflicting reports about the action of neuroleptics, like haloperidol, in PCP- or ketamine-induced psychosis. In this experiment with already psychotic patients, haloperidol did not prevent a ketamine-induced worsening in mental status. Indeed, the increase in psychotic symptoms was only significant while patients were on haloperidol. However, the lack of significant worsening in the off-HAL condition may simply be due to the smaller sample size and/or a higher baseline level of psychosis with the occurrence of a ceiling effect for psychosis. Other effects such as pharmacokinetic factors may contribute. In addition, the increase in the on-HAL condition was not significantly different from the increase in the off-HAL condition when comparing those subjects who completed both sets of challenges.

The experiences of schizophrenic patients with ketamine appear to be significantly different from those of normals given an infusion of ketamine over 40 minutes (Krystal et al. 1994). Although, in normals, ketamine produced a dose-dependent increase in psychoticlike phenomenon, these were limited to illusions, perceptual alterations, thought disorder, and suspiciousness; hallucinations did not occur. In normals, there was an increase in negative symptoms, including emotional blunting and difficulties in task performance. Schizophrenics showed both frank psychosis and an absence of negative symptoms. However, the difference in the technique and duration of drug administration (acute bolus vs. subacute infusion) makes it difficult to compare symptoms directly in these two data sets. Despite that, it is tempting to speculate that a preexisting level of endogenous psychosis in schizophrenia influences (i.e., sensitizes) the action of ketamine on mental status.

Our preliminary observations of delayed psychotic symptoms, spontaneously reported by several volunteers, occurred well beyond the half-life of the drug. Most of the delayed symptoms such as the reexperience of visual hallucinations and the reonset of paranoid delusions emerged after complete acute resolution of the primary ketamine action. These observations were only reported by 4 out of the 9 patients and should be interpreted with care. Several reasons independent of the ketamine challenge might explain why this could have happened. However, this same phenomenon has been previously reported after PCP both with its illicit use (Aniline and Pitt 1982; Rainey and Crowder 1975) and with its experimental evaluation after anesthesia (Moretti et al. 1984). Animal studies of PCP have suggested several different possible mechanisms for such a delayed effect. Gao and Tamminga (1994) reported a prolonged (12-24 hours) increase in NMDA-sensitive $\left({ }^{3} \mathrm{H}\right)$-glutamate binding in the hippocampus after a single dose of PCP.

Based on primary research experience with several different psychotomimetic drugs in schizophrenia, we would suggest that ketamine stimulates the symptoms of schizophrenia in a unique way. Whereas other psychotomimetic compounds produce usual psychotomimetic experiences in schizophrenics, they do not charac- 
teristically produce symptoms of the person's own illness, as does ketamine here (Angrist et al. 1980; Foster et al. 1983; Tamminga et al. 1978). Several previous studies have compared the effects of a range of psychotomimetic drugs in normal volunteers with the symptoms of schizophrenic illness. Reports are mixed in the support, or lack thereof, of similarities between drug-induced symptoms and endogenous psychosis (Angrist and Gershon 1970; Bell 1965; Griffith 1970a,b 1972; Janowsky and Risch 1979; Mitchell and Vierkant 1991; Sherer et al. 1988; Unnithan and Cutting 1992). With chronic use of amphetamine or cocaine, schizophrenic patients relapse (Knudsen and Vilmar 1984; Treffert 1978). In a review of 36 psychotomimeticchallenge studies, Lieberman et al. (1987) found that overall $40 \%$ of schizophrenic patients and $35 \%$ of stabilized psychotic subjects had an increase in psychosis with the drug during an acute challenge; only $3 \%$ of control humans had a psychosis response. But he does not indicate whether these drugs triggered "pathologyspecific" psychotic symptoms or just idiosyncratic drug symptoms. In an attempt to address the question of the specificity of symptoms triggered by different psychotomimetics, Pennes (1954) compared the mental status changes provoked in the same schizophrenic subject by different drugs, including amytal, pervitin, mescaline, and LSD. He concluded that there appeared to be a basic idiosyncratic drug action specific for each psychotomimetic drug and that the effects of a drug tend to occur in a stereotyped form in subjects together with changes that are specific for each subject. That ketamine appears to stimulate endogenous psychosis in schizophrenia might suggest that blockade of glutamatergic transmission at the NMDA receptor is "close" to the pathophysiology of schizophrenic psychosis, because, unlike other psychotomimetic compounds, ketamine-induced symptoms look like their illness.

In conclusion, ketamine, a structural analogue of $\mathrm{PCP}$, induces a dose-dependent, short-lasting increase in psychotic symptoms in stable schizophrenic volunteers often reminiscent of their own acute symptoms. Because the behavioral effect is dose-dependent and the ketamine dose range is compatible with its action at the NMDA receptor, it supports the proposition that this effect is mediated through the NMDA receptor. Haloperidol failed to block the psychosis-inducing action of ketamine, an effect which deserves further study. Behavioral and anatomical characterization of this drug-induced psychosis may help our understanding of schizophrenia and have obvious treatment implications.

\section{ACKNOWLEDGMENTS}

This work was supported in part by the National Institute of Mental Health Grant MH CRC 40279. The authors wish to thank the staff of the Residential Research Unit of the Maryland Psychiatric Research Center for their excellent clinical assistance; Jonathan Nevitt for data collection and analysis; Deborah Medoff, Ph.D., for her expert statistical assistance and review of the manuscript; and Kristin Ricasa for her excellent technical assistance.

\section{REFERENCES}

Andreasen NC (1982): Negative symptoms of schizophrenia: Definitions and reliability. Arch Gen Psychiatry 39:784788

Angrist BM, Gershon S (1970): The phenomenology of experimentally induced amphetamine psychosis: Preliminary observations. Biol Psychiatry 2:95-107

Angrist B, Rotrosen J, Gershon S (1980): Responses to apomorphine, amphetamine, and neuroleptics in schizophrenic subjects. Psychopharmacology (Berlin) 67:31-38

Aniline O, Pitts FN (1982): Phencyclidine (PCP): A review and perspectives. CRC Crit Rev Toxicol 10:145-177

Anis NA, Berry SC, Burton NR, Lodge D (1983): The dissociative anesthetics ketamine and phencyclidine selectively reduce excitation of central mammalian neurons by $\mathrm{N}$-methyl-D-aspartate. Br J Pharmacol 79:5654-5675

Bakker CB, Amini FB (1961): Observations on the psychotomimetic effects of sernyl. Comp Psychiatry 2:269-280

Bell DS (1965): A comparison of amphetamine psychosis and schizophrenia. Br J Psychiatry 3:701-707

Buchanan RW, Heinrichs DW (1989): The neurological evaluation scale (NES): A structured instrument for the assessment of neurological signs in schizophrenia. Psychiatry Res 27:335-350

Burns RS, Lerner SE (1976): Perspectives: Acute phencyclidine intoxication. Clin Toxicol 8:477-501

Cannon-Spoor HE, Potkin SP, Wyatt RJ (1982): Measurement of premorbid adjustment in chronic schizophrenia. Schizophren Bull 8:470-484

Castellani S, Adams PM (1981): Effects of dopaminergic drugs on phencyclidine-induced behavior in the rat. Neuropharmacology 20(4):371-374

Collins VJ, Gorospe CA, Rovenstine EA (1960): Intravenous nonbarbiturate, non-narcotic analgesics: Preliminary studies. Anesth Analg 39:303-306

Coppel DW, Bowill JG, Dundee JW (1973): The taming of ketamine. Anaesthesia 28:293-296

Deakin JF, Slater P, Simpson MD, Gilchrist AC, Skan WJ, Royston MC, Reynolds GP, Cross AJ (1989): Frontal cortical and left temporal glutamatergic dysfunction in schizophrenia. J Neurochem 52:1781-1786

Erard R, Luisada PV, Peele R (1980): The PCP psychosis: Prolonged intoxication or drug-precipitated functional illness? Psychedel Drugs 12:235-245

Fine J, Finestone SC (1973): Sensory disturbances following ketamine anesthesia; Recurrent hallucinations. Anesth Analg 52:429-430

Foster NL, Chase TN, Denaro A, Hare TA, Tamminga CA (1983): THIP treatment of Huntington's disease. Neurology 33:637-639

Freuchen I, Ostergaard J, Kuhl JG, Mikkels BO (1976): Reduction of psychotomimetic side effects of ketelar (ketamine) 
by Rohypnol (flunitrazapam). Acta Anesthesiol Scand 20:97-103

Gao X-M, Tamminga CA (1994): An increase in NMDAsensitive ${ }^{3} \mathrm{H}$-glutamate and ${ }^{3} \mathrm{H}$-kainate binding in hippocampus 24 hours after PCP. Neurosci Lett 174:149-153

Gao XM, Shirakawa O, Du F, Tamminga CA (1993): Delayed regional metabolic actions of phencyclidine. Eur J Pharmacol 241:7-15

Gattaz WF, Gasser T, Beckmann H (1985): Multidimensional analysis of the concentrations of 17 substances in the CSF of schizophrenics and controls. Biol Psychiatry 20: 360-366

Griffith JD, Cavanaugh JH, Held J (1970a): Experimental psychosis induced by the administration of d-amphetamine. In Costa D, Garattini S (eds), Amphetamines and Related Compounds, New York, Raven

Griffith JD, Cavanaugh JH, Oates JA (1970b): Psychosis induced by the administration of d-amphetamine to human volunteers. In (ed), Efron DH, Psychotomimetic Drugs. New York, Raven

Griffith JD, Cavanaugh J, Held J (1972): Dextroamphetamine: Evaluation of psychomimetic properties in man. Arch Gen Psychiatry 26:97-100

Gupta RC, Lu I, Oei GL, Lundbergh GD (1975): Determination of phencyclidine (PCP) in urine and illicit street drug samples. Clin Toxicol 8: 611-621

Guy W (1976): Assessment Manual for Psychopharmacology [DHEW No. (ADM) 76-338) Rockville, MD, National Institute of Mental Health

Hedlund JL, Vieweg BW (1980): The Brief Psychiatric Rating Scale (BPRS): A comprehensive review. J Oper Psychiatry 11:48-64

Heija P, Galloon S (1975): A consideration of ketamine dreams. Can Anaesth Soc J 22:100-105

Janowsky DS, Risch C (1979): Amphetamine psychosis and psychotic symptoms. Psychopharmacology 65:73-77

Javitt DC, Zukin SR (1991a): Mechanisms of phencyclidine (PCP) N-methyl-D-aspartate (NMDA) receptor interaction: Implications for schizophrenia. In Schulz SC, Tamminga CA (eds), Schizophrenia: Research Progress, vol 1. New York, Raven, pp 12-19

Javitt DC, Zukin SR (1991b): Recent advances in the phencyclidine model of schizophrenia. Am J Psychiatry 148 (10):1301-1308

Kerwin R, Patel S, Meldrum B (1990): Quantitative autoradiographic analysis of glutamate binding sites in the hippocampal formation in normal and schizophrenic brain postmortem. Neurosci 39:25-32

Kim J, DeCola JP, Landeira-Fernandez J, Fanselow MS (1991): $\mathrm{N}$-methyl-D-aspartate receptor antagonist APV blocks acquisition but not expression of fear conditioning. Behav Neurosci 105(1):126-133

Kirkpatrick B, Buchanan RW, McKenney PD, Alphs LD, Carpenter WT (1989): The schedule for the deficit syndrome: An instrument for research in schizophrenia. Psychiatry Res 30:119-123

Knudsen P, Vilmar T (1984): Cannabis and neuroleptic agents in schizophrenia. Acta Psychiatr Scand 69:162-174

Kornhuber J, Mack-Burkhardt F, Riederer P, Hebenstreit GF, Reynolds GP, Andrews HB, Beckmann H (1989): $\left[{ }^{3} \mathrm{H}\right] \mathrm{MK}-801$ binding sites in postmortem brain regions of schizophrenic patients. J Neural Transm 77:231-236

KorpiER, Kaufmann CA, Marnela KM, Weinberger DR (1987): Cerebrospinal fluid amino acid concentrations in chronic schizophrenia. Psychiatry Res 20:337-345

Krystal JH, Karper LP, Seibyl JP, Freeman GK, Delaney R, Bremmer JD, Heninger GR, Bowers MB Jr, Charney DS (1994): Subanesthetic effects of the noncompetitive NMDA antagonist, ketamine in humans: Psychotomimetic, perceptual, cognitive and neuroendocrine responses. Arch Gen Psychiatry 51:199-214

Kurumaji A, Ishimaru M, Toru M (1992): a- $\left[{ }^{3} \mathrm{H}\right]$ Amino-3hydroxy-5-methylisoxazole-4-propionic acid binding to human cerebral cortical membranes: Minimal changes in postmortem brains of chronic schizophrenics. J Neurochem 59:829-837

Lieberman JA, Kane JM, Alvir J (1987): Provocative tests with psychostimulant drugs in schizophrenia. Psychopharmacology 91:415-433

Luby ED, Cohen BD, Rosenbaum G, Gottlieb JS, Kelley R (1959): Study of a new schizophrenomimetic drugSernyl. Arch Gen Psychiatry 81:363-369

Macciardi F, Lucca A, Catalano M, Marino C, Zanardi R, Smeraldi E (1990): Amino acid patterns in schizophrenia: Some new findings. Psychiatry Res 32:63-70

Malare A, Holsapple MP, Yim GK (1982): Reduction by atropine of phencyclidine hypertension and apneusis. Life Sci 30(11):929-934

Mitchell J, Vierkant AD (1991): Delusions and hallucinations of cocaine abusers and paranoid schizophrenics: A comparative study. J Psychol 125(3):301-310

Monyer H, Burnashev N, Laurie DJ, Sakmann B, Seeburg $\mathrm{PH}$ (1994): Developmental and regional expression in the rat brain and functional properties of four NMDA receptors. Neuron 12:529-540

Moretti RJ, Hassan SZ, Goodman LI, Meltzer HY (1984): Comparison of ketamine and thiopental in healthy volunteers. Anesth Analg 63:1087-1096

Nabeshima T, Sivam SP, Norris JC, Ho IK (1981): Calciumdependent GABA release from mouse brain slices following acute and chronic phencyclidine administration Res Commun Subst Abuse 2:343

Nishikawa T, Takashima M, Toru M (1983): Increased $\left[{ }^{3} \mathrm{H}\right]-$ kainic acid binding in the prefrontal cortex in schizophrenia. Neurosci Lett 40:245-250

Olney JW, Labruyere J, Price MT (1989): Pathological changes induced in cerebrocortical neurons by phencyclidine and related drugs. Science 244:1360

Overall JE, Gorham DR (1962): The brief psychiatric rating scale. Psychol Rep 10:799-812

Pearlson GD (1981): Psychiatric and medical syndromes associated with phencyclidine (PCP) abuse. Johns Hopkins Med J 148:25-33

Pennes HH (1954): Clinical reactions of schizophrenics to sodium amytal, pervitin hydrochloride, mescaline sulfate, and d-lysergic acid diethylamide ( $\left.\mathrm{LSD}_{25}\right)$. J Nerv Ment Dis 119:95-112

Potkin SG, Costa J, Roy S, Sramek J, Jin Y, Gulasekarem B (1992): Glycine in the treatment of schizophrenia: Theory and preliminary results. In HY Meltzer (ed), Novel Antipsychotic Drugs. New York, Raven, pp 179-188 
Rainey JM, Crowder MK (1975): Prolonged psychosis attributed to phencyclidine: Report of three cases. Am J Psychiatry 132(10):1076-1078

Raja SN, Guyenet PG (1980): Effects of phencyclidine on the spontaneous activity of monoaminergic neurons. Eur J Pharmacol 63(2/3):229-233

Sharp FR, Butman M, Wang S, Koistinaho J, Graham SH, Sagar SM, Noble L, Berger P, Longo FM (1992): Haloperidol prevents induction of the hsp70 heat shock gene in neurons injured by phencyclidine (PCP), MK801, and ketamine. J Neurosci Res 33:605-616

Sherer MA, Kumor KM, Cone EJ, Jaffe JH (1988): Suspiciousness induced by four-hour intravenous infusions of cocaine. Arch Gen Psychiatry 45:673-677

Sherman AD, Hegwood TS, Baruah S, Waziri R (1991): Deficient NMDA-mediated glutamate release from synaptosomes of schizophrenics. Biol Psychiatry 20:11911198

Smith RC, Strizich M, Klass D (1980): History of neuroleptic drugs and tardive dyskinesia. In Fann WE, Smith RC, Davis JM, Domino EF (eds), Tardive Dyskinesia: Research and Treatment. New York, SP Medical \& Scientific Books, pp 152-158

Strauss JS, Carpenter WT (1974): The prediction of outcome in schizophrenia. Arch Gen Psychiatry 31:37-42

Suga I, Kogayashi T, Ogata H (1990): Increased 3H-MK801 binding in post-mortem brains of chronic schizophrenic patients. The Satellite Symposium of the 17th CINPResearch Abstracts, p 28

Tamminga CA, Crayton JW, Chase TN (1978): Muscimol: GABA agonist therapy in schizophrenia. Am J Psychiatry 135:746-747
Tamminga CA, Cascella N, Fakouhi TD, Herting RL (1992): Enhancement of NMDA-mediated transmission in schizophrenia. In Meltzer HY (ed), Novel Antipsychotic Drugs. New York, Raven, pp 171-177

Thomson AM, West DC, Lodge D (1985): An N-methylaspartate receptor-mediated synapse in rat cerebral cortex: A site of action of ketamine? Nature 313:479-481

Tonge SR, Leonard BE (1969): The effects of some hallucinogenic drugs upon the metabolism of 5-hydroxytryptamine in the brain. Life Sci 8(15):805-814

Toru M, Watanabe S, Shibuya H, Nishikawa T, Noda K, Mitsushio H, Ichikawa H, Kurumaji A, Takashima M, Mataga N (1988): Neurotransmitters, receptors and neuropeptides in post-mortem brains of chronic schizophrenic patients. Acta Psychiatr Scand 78:121-137

Treffert DA (1978): Marijuana use in schizophrenia: A clear hazard. Am J Psychiatry 135(10):1213-1215

Ulas J, Cotman CW (1993): Excitatory amino acid receptors in schizophrenia. Schizophren Bull 19:105-117

Unnithan SB, Cutting JC (1992): The cocaine experience: Refuting the concept of a model psychosis. Psychopathology $25(2): 71-78$

Watkins JC, Collingridge GL (1989): The NMDA Receptor. Oxford, Oxford University Press.

White PF, Way WL, Trevor AJ (1982): Ketamine-Its pharmacology and therapeutic uses. Anesthesiology 56: 119-136

Yesavage JA, Freeman AM III (1978): Acute phencyclidine (PCP) intoxication: Psychopathology and prognosis. J Clin Psychiatry 44:664-665 